Ann. Génét. Sél. Anim., I977, 9 (I), 47I-49I

\title{
Survey of recent situation of chromosome pathology in different breeds of german cattle ${ }^{(1)}$
}

\author{
A. HERZOG, Henni HÖHN et G. W. RIECK \\ Institut für Zuchthygiene und Veterinärmedizinische Genetik \\ der Justus-Liebig-Universität Giessen, Hofmannstrasse Io \\ D-63oo Giessen (Bundesrep. Deutschland)
}

\section{Summary}

r. With the aim to elucidate the etiological role of chromosome anomalies in pathology of domestic animals karyotype analyses had been performed routinically in 847 newborn calves with congenital malformations, furthermore in adult cattle with hereditary diseases, andin individuals with malformations of genital organs. The investigations have been realized during the past Io years within the three large breeds of the cattle population of Hessen. Chromosome anomalies of different types have been found in I4I probands.

2. Considering the impossibility in karyotyping all calves with congenital anomalies extensively, most of them being stillborn, and in regard of the impractibility of a cytogenetic exploration of whole the population, it seems to be impossible to derive more than rough estimations of the real frequencies of chromosome anomalies within the observed population.

3. The first rank of different types of chromosome anomalies is occupied by the $\mathrm{r} / 29$ translocation, followed by the trisomy I 8 . (In this connection the XX/XY chimerism in freemartins is not taken in consideration because its frequency is depending exclusively from the frequencies of heterozygous twins within the different breeds). Considering their real frequencies both types of chromosome anomalies dont possess a noteworthy economical importance within the observed population in the present situation. All other chromosomal anomalies, especially autosomal structural defects, too, are found only sporadically, though accumulated in certain families. This is the case in bovine hereditary parakeratosis, and in hereditary nanism.

4. The occurrence of several probands with the trisomy i 8 syndrome (lethal brachygnathia trisomy syndrome) in a family together with gonosomal numerical anomalies is estimated to be the expression of a familiar disposition to disturbances of meiosis, resp. mitosis.

5. On the basis of autopsy findings in 18 cases of trisomy 18 syndrome, and those of 9 cases of bovine hereditary parakeratosis the symptomatology of those, by chromosome anomalies caused, resp. with chromosome anomalies combined, syndromes was determined. Significantly increased frequencies of autosomal breaks in parents of parakeratosis calves may be used as markers in order to identify heterozygotes in families suspected of this hereditary disturbance of zinc metabolism.

(r) This article has been presented to the 3 rd Colloquium of Cytogenetics of Domestic animals, May 3I-June 2 I977, Jouy-en-Josas, France. 


\section{Introduction}

The following report presents the results of systematic cytogenetic studies in newborn calves with congenital malformations, in adult individuals with disturbances of sex differentiation, and those which have been fallen sick with maladies caused by (or combined with) chromosomal aberrations. Those results have been obtained in the regional population of cattle in Hessen (Fed. Repub1. of Germany), composed of the four breeds Black Pied Lowland (partially HolsteinFriesian), Red Pied Lowlands, German Simmental (Fleckvieh), and German Red Cattle, during I968 till May 1977.

The report offers a review of prior papers of the authors emphazising recent advances in etiological and nosological research in Bovine Hereditary Parakeratosis, and the Trisomy I 8 Syndrome.

The results of cytogenetic observations reported in this paper are not derived from systematic investigation of whole the population, but the sample of karyotyped animals collected from the population is preselected regarding pathological traits of the animals only. Therefore, it seems to be inconvenient to derive out of those figures presented in Table I statistically established informations about the frequencies of chromosomal defects within the population, and differences of chromosomal defects within the population, and differences of frequencies between the breeds. But, if we compare the percentages of chromosomal anomalies with the numbers of examined animals belonging to the different breeds, extending from 3.8 p. cent in Black Pied Lowlands (partially Holstein-Friesian), 2.7 p. cent in Red Pied Lowlands, to I4.I p. cent in the German Simmental Cattle (Table 2) we may establish the number of chromosomal aberrations being biased in disfavour of the Simmental breed. The real relations of percentages of chromosomal anomalies to the percentages of breeds composing the population you may evaluate by a short glance at the left column of Table $z$.

Table I exhibit that regularly only three types of structural and numerical. autosomal aberrations are found in the observed population associated with different pathological traits of newborn calves or of adult patients during the last five years. Incidentally or seldom gonosomal numerical aberrations are observed, except the $\mathrm{XX} / \mathrm{XY}$ chimerism, which is not from interest in this connection, mainly four types of them. The roughly estimated frequencies of the different types of autosomal anomalies are differing in wide range; none of them gained a remarkable expansion with corresponding economical importance.

\section{1. - Structural autosomal anomalies}

a) From this group the $I / 29$ translocation take with $I 3$ cases the first rank in the order of precedence in the breed of German Simmentals, followed by the trisomy $I 8$ in all breeds. The translocations, identified by different methods of banding technique, were represented only by the I/29 type. Other types, f.i. the $I / 25$ translocation, STRANZINGER and FürSTER (I976) found within a family of German Simmental of Bavaria, or those of HARVEY and LOGUE (I975) who identified a new I3/2I translocation in the Swiss Simmental breed, did'nt occur till this very moment in our breeds. In contrast to the observations of GusTavsson et al., who saw distinct repression of fertility in translocation heterozygotes, in our breeds all female translocation bearers revealed an undisturbed fertility. The discre- 


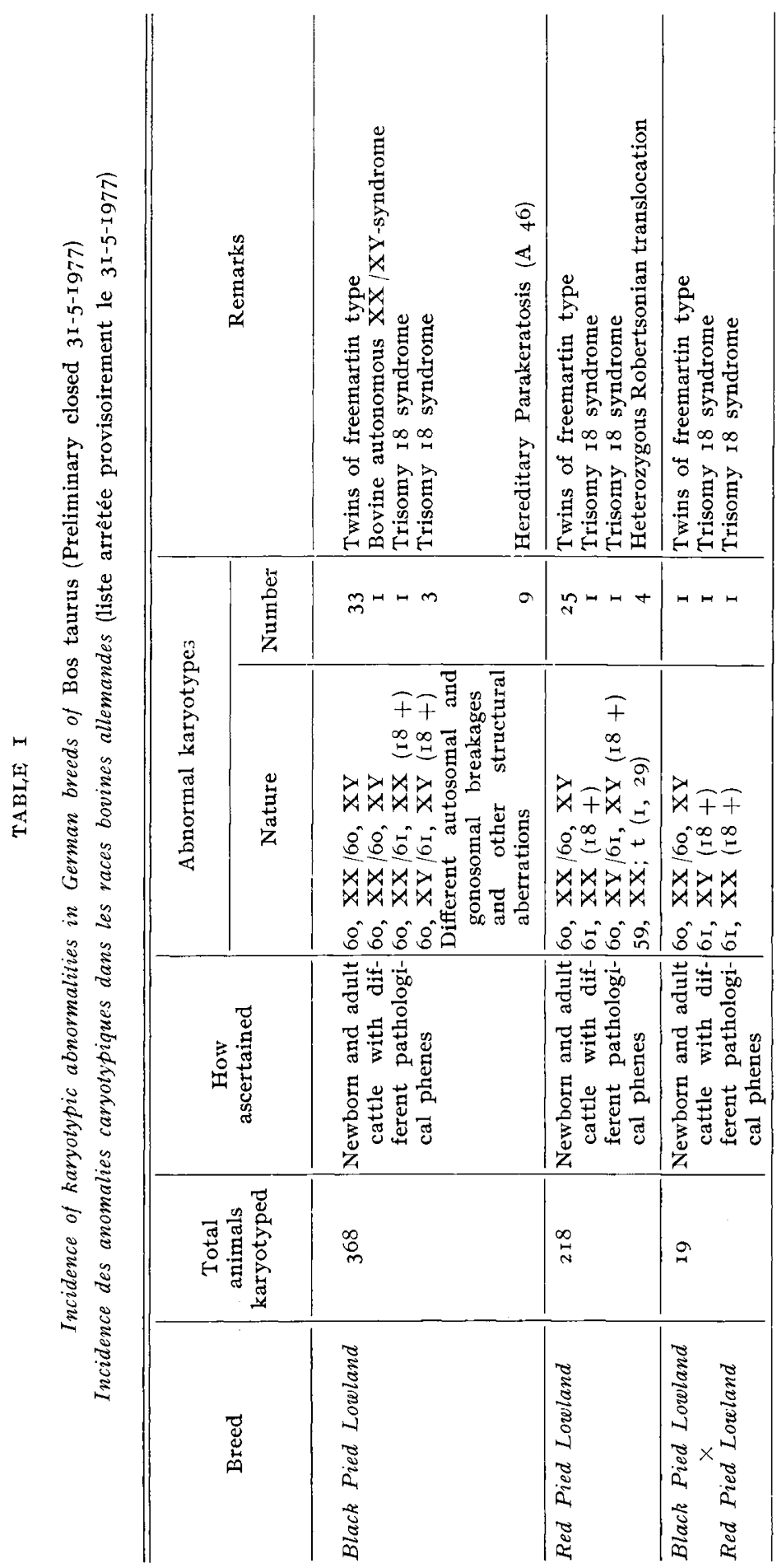


A. HERZOG, H. HÖHN, G. W. RIECK

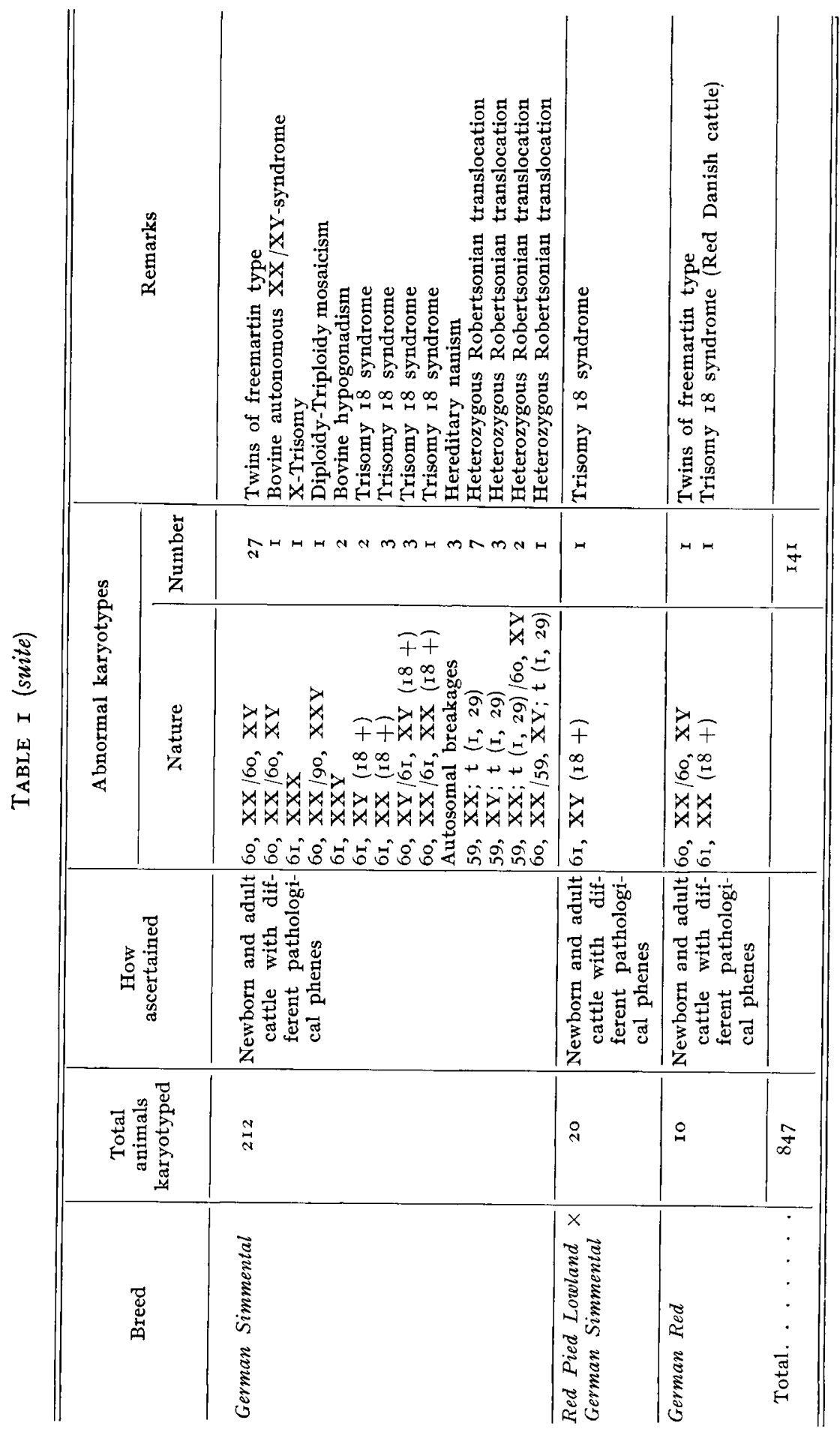


TABLE 2

Structure of cattle population, $i$. e. percentages of breeds, in the observed recion and number of karyotyped animals (1968-V/1977)

Structure de la population bovine, pourcentages d'animaux dans chaque race présentée dans la région observée et nombre d'animaux étudiés (1968 à 1977)

\begin{tabular}{|c|c|c|c|c|}
\hline \multirow{2}{*}{ Percentage of breeds in population } & \multicolumn{4}{|c|}{ Karyotyped animals } \\
\hline & Normal & Pathologic $\left({ }^{*}\right)$ & Total & $\%$ \\
\hline 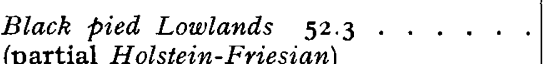 & 5 & 368 & 373 & 3.8 \\
\hline 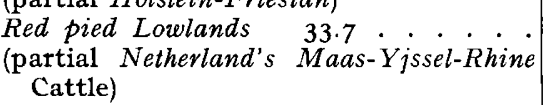 & 5 & 218 & 223 & 2.7 \\
\hline $\begin{array}{lc}\text { German Fleckvieh } & \text { I2.3 } \\
\text { (German Simmental) } & \\
\text { German Red and } & \\
\text { Yellow Cattle } & \\
\text { (partial Red Danish Milk Cattle) }\end{array}$ & $9 \mathrm{I}$ & 212 & 303 & $\mathbf{1 4 . I}$ \\
\hline
\end{tabular}

(*) Different pathologic traits, especially congenital malformations of different types.

(*) Différents traits pathologiques, surtout les malformations congénitales des différents types.

pancies between the phenotypical effects of translocations in Swedish and Norwegian breeds (REFSDAL, I976) probably are attributed to the comparatively very small sample of karyotyped animals corresponding to the low distribution of translocations in our breeds.

\section{b) - Autosomal aberrations in Bovine hereditary parakeratosis (BHP)}

Since 1960 it has been observed in several regions of the world a metabolic disturbance in Holstein-Friesian breed, which very soon had been recognized to be caused by a nutrient zinc deficiency (MILLER and MILLER, I960), which is connected with more or less severe lesions of the skin in the sense of parakeratotic dermatosis and other pathological traits. The hereditary etiology of this syndrome, originally named " parakeratosis " (LEGG and SEARS, I960), had been first stated in Denmark by ANDRESEN et al. (I970), who described a new lethal trait, A 46 , found in the descent of a Friesian bull belonging to the wide spread group of Friesian bulls named ADEMA (" ADEMA disease") (WEISMANN and FLAGSTAD, I976). Later on STÖBER (I97I) and TRAUTWEIN (I97I) confirmed such observations by own investigations in Holstein-Friesian calves in North-West-Germany. The chromosomal situation of those animals have been explored by HERzoG and HöHN (I97I) who, for the first time found typical autosomal defects in all parakeratotic patients, which consist in chromatid and isochromatid breaks and different types of autosomal associations (quadri- and triradial figures), gaps, dicentric and acentric chromosomes (fig. I).

The Hereditary Parakeratosis is caused by an autosomal recessive Mendelian factor, and is manifesting in an age of $4-8$ weeks with the symptoms of stomatitis, 


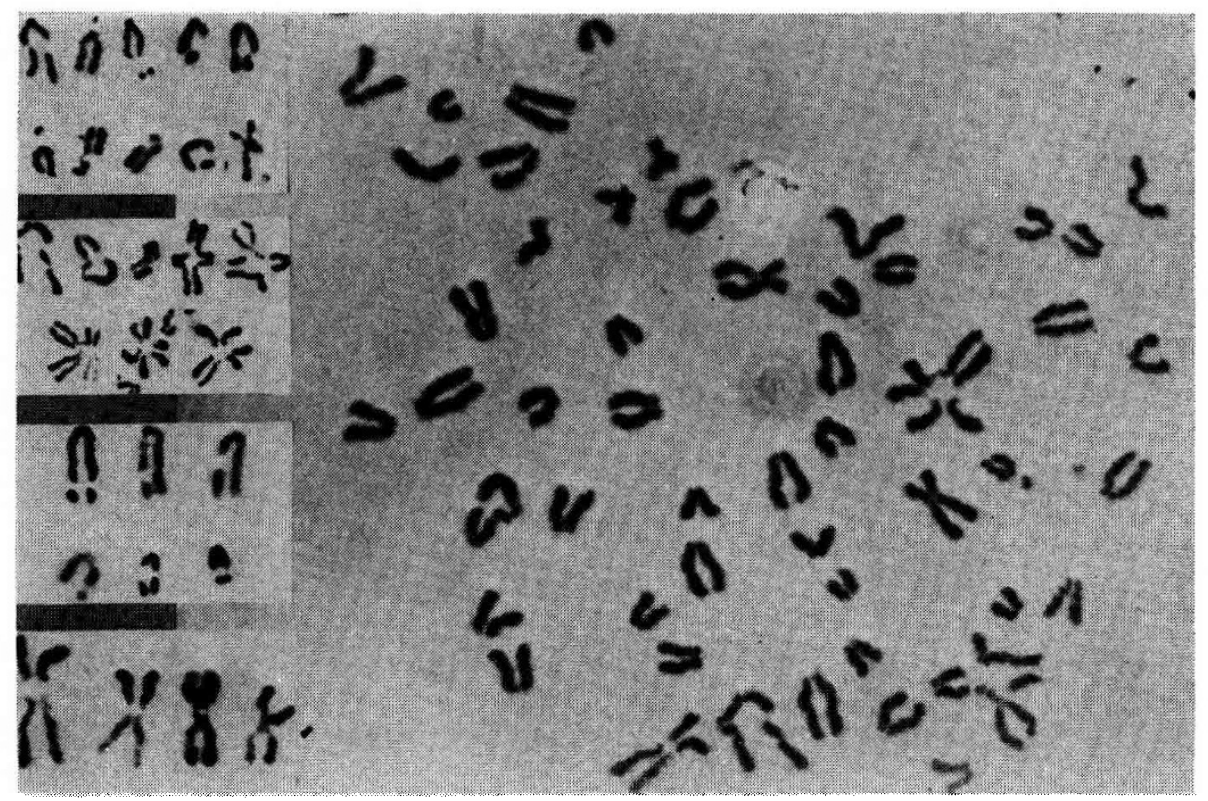

FIC. I. - One of the metaphases being typical for Hereditary parakeratosis in bovine showing several types of association figures. Left edge: $A$ collection of different types of breaks, gaps and association figures originating from several patients suffering from BHP. - All autosomal aberrations found in BHP are resembling largely those of human BLOOM's syndrome, and FANcoNI's syndrome.

Métaphase typique d'un animal atteint de parakératose bovine montrant plusieurs types d'association. Côté gauche : Différents types de cassures, coupures et associations trouvés chez plusieurs animaux souffrant de BHP. Toutes les aberrations autosomales trouvées chez BHP ressemblent à celles des syndromes de BLOOM et de FANconI chez les humains.

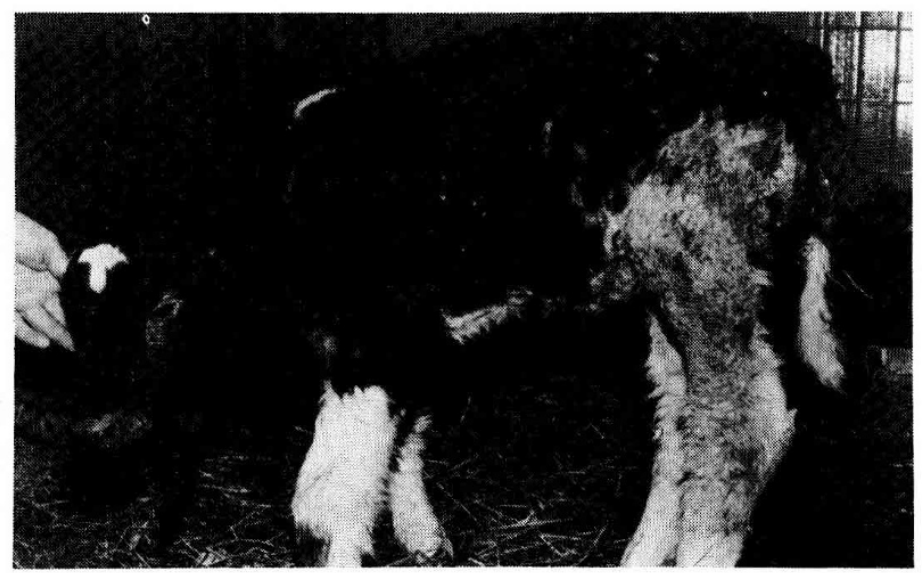

FIG. 2. - Widespread parakeratotic dermatoses in the regions of thighs, abdomen, environments of eyes and of muzzle. The patient died with pneumonia (increased disposition to intectious diseases!). Black Pied Lowland calf, Reg. No. $4263 / 77$.

Dermatoses parakératosiques étendues dans les régions des cuisses, de l'abdomen, autour des yeux et du museau. Plus tard l'animal est mort d'une pneumonie (prédisposition accrue pour les maladies infectieuses). Veau Pie noir des Plaines, cas $n^{\circ} 4263 / 77$. 
conjunctivitis, widespread dermatoses (fig. 2), retardation of development with lethal effect within 4-6 months except the patients are treated with zinc substitution.

\section{Autosomal breakages markers in heterozygotes for Bovine Hereditary Parakeratosis?}

Originally, there aroused some doubts wether the chromosome anomalies observed in patients with BHP are acting a role in the etiology of this lethal trait, but, rather only being one symptom of this syndrome together with several others. But, the demonstration of the chromosome anomalies described above in all patients with BHP (Table 3), and, moreover the observation of breakages in metaphases of white blood cells in the parents of BHP calves with few exceptions seem to elucidate a more important role of those autosomal structural defects in pathogenesis of this metabolic disturbance. Table 4 is demonstrating a frequency of breaks in autosomes of fathers of HP calves of II.I p. cent, and in those of mothers of $9.5 \mathrm{p}$. cent on the average of all karyotyped parents. In comparison with the frequencies of breaks in the normal Black Pied Lowlands population of Germany from 0-0.028 p. cent (EL-NAHAss et al., I976) to 4.I p. cent in an own control sample (Table 5) the difference between the values of II.I p. cent resp. 9.5 p. cent and of 1.5 p. cent are significant.

TABLE 3

Autosomal breakages and other structural anomalies in metaphases of white blood cells from calves suffering with BHP

Cassures autosomales et autres anomalies structurales dans les métaphases de globules blancs de veaux atteints de BHP

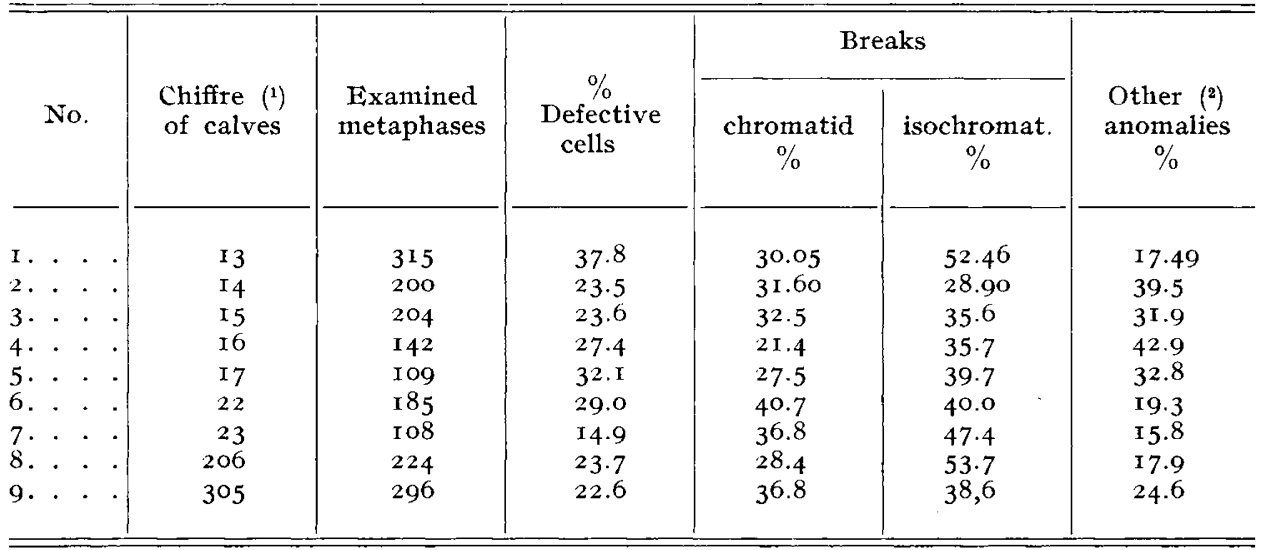

COMMENT: The calves No. $I, 4$ and 5 suffered in the time of blood sampling with an acute BHP without therapy, whereas the other calves already had been substituted with $Z n C O_{3}$. The therapy with $Z n$ exhibit a decreasing effect on the frequencies of chromosomal anomalies.

REMARQUE : Les veaux $\mathrm{N}^{\circ} \mathrm{I}, 4$ et 5 , souffraient, à l'époque de la prise de sang, d'un BHP aigu, il n'était pas soigné tandis que les autres veaux recevaient déjà $Z \mathrm{ZnCO}_{3}$. Le traitement au zinc a entraîné une diminution de la fréquence des anomalies chromosomiques. (I974).

(r) The chiffres of calves correspond with those in the paper of StöBER, Pitrermann and KLUG

(2) Anomalies other than chromatid and isochromatid breaks, such as gaps, centromeric briaks, acentric fragments, association figures, polyploid cells. 


\section{TABLE 4}

Autosomal breaks in metaphases of white blood cells of parents of parakeratosis calves (Breed: Black Pied Lowlands)

Cassures autosomales dans les métaphases de globules blancs chez des parents de veaux atteints de parakératose

(race: Pie noir des Plaines)

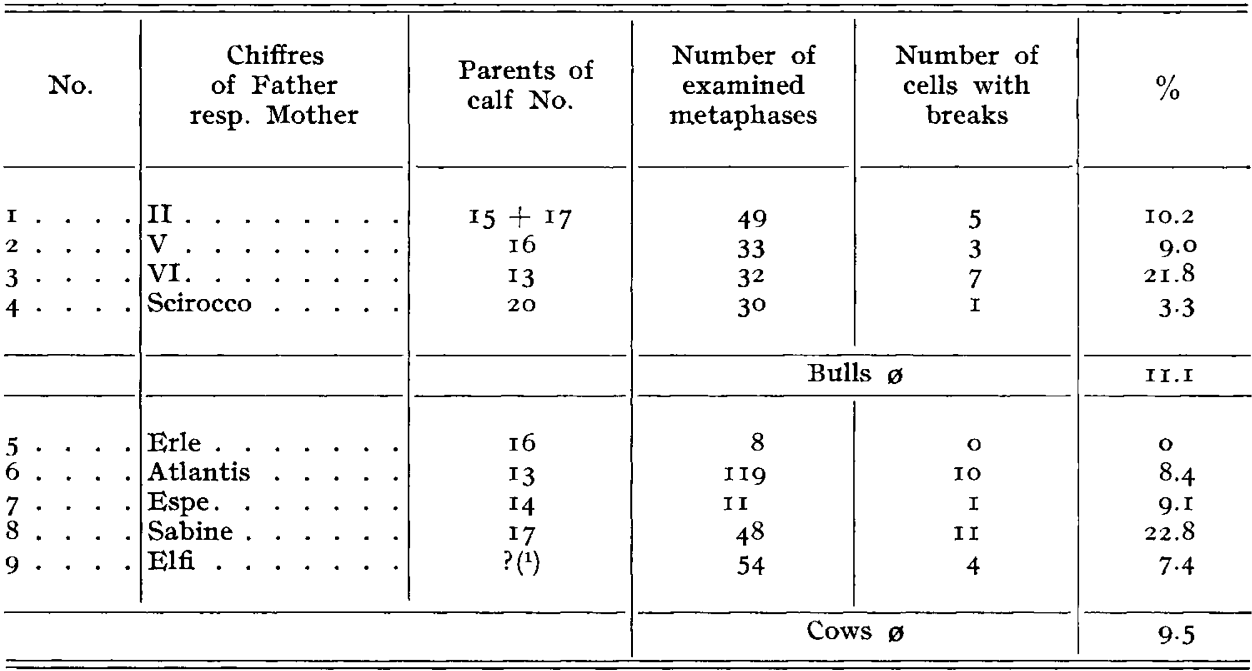

(I) Mother of a calf which died from acute BHP without karyotype analysis.

(I) Mère d'un veau qui mourut d'un BHP aigu sans analyse caryotypique.

\section{TABLE 5}

Autosomal breaks in a group of unsuspicious Black Pied Lowland bulls used in A.I. (Control group)

Cassures autosomales dans un groupe de taureaux d'insémination non suspects de parakératose (groupe témoin)

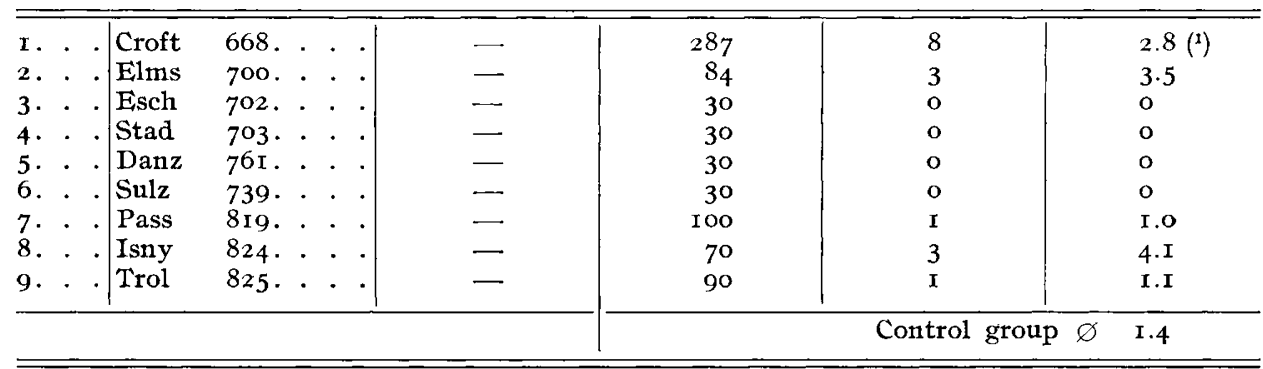

Annotation: The significance of the difference between the means of relative frequencies of cells with autosomal breaks within parents of parakeratosis calves (Table 4) and within the control group (Table 5) have been proved by the $U$-test corresponding to MANN-WHITNEY-WILCOXON at a level of $\alpha=0.0 \mathrm{I}$.

Remarque: L'étude de la signification de la différence entre les moyennes des fréquences relatives des cellules porteuses de carences autosomales chez les parents des veaux atteints de parakératose (tabl. 4) et entre le groupe de contrôle (tabl. 5) a été fait à l'aide du test U qui correspond à MANN-WHITNEY, WILCoxon au seuil de $\alpha=0$,or.

(I) Karyotyped on behalf of lack of libido; all other routinically. 
Therefore, it seems to be justified to declare relatively high frequencies of autosomal breaks to be characteristic for the heterozygous condition of the gene "Hereditary Parakeratosis". In bovine adults suspicious to be heterozygous for BHP, autosomal breaks exceeding a limit of about $5 \mathrm{p}$. cent may assigned to detect heterozygosity. Self-evident, this assertion must not neglect the fact, that some other causes may produce structural defects in chromosomes than BHP.

\section{c. - Autosomal breaks in cases of Hereditary Nanism}

Autosomal breaks too had been observed in 1976 in three calves belonging to the sibship of a Simmental bull bred in Baden-Wuirttemberg. This bull brought about 25 p. cent dwarf calves within his offspring, obviously being heterozygous for an autosomal quasi dominant Mendel factor "Hereditary Nanism ", a viable non chondrodysplastic, proportionate dwarfism. The breaks occurring in the first blood sample in frequencies of about 30-43 p. cent of metaphases of white blood cells diminished in the course of one month about $50 \mathrm{p}$. cent (Table 6). The father of the dwarf calves didn't exhibit any chromosome anomaly.

\section{TABLE 6}

Frequencies of autosomal breaks in calves with hereditary nanism

(Breed: German Simmental)

Fréquences des cassures autosomales chez des veaux atteints de nanisme héréditaire (race: Simmental allemande)

\begin{tabular}{|c|c|c|c|}
\hline Chiffre of calf & $\begin{array}{l}\text { Date of blood } \\
\text { sampling }\end{array}$ & $\begin{array}{c}\text { Number } \\
\text { of examined cells }\end{array}$ & $\begin{array}{c}\% \\
\text { Breaks }\end{array}$ \\
\hline 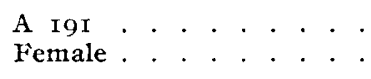 & $\begin{array}{l}6-9-76 \\
4-x 0-76\end{array}$ & $\begin{array}{l}\text { roo } \\
\text { 100 }\end{array}$ & $\begin{array}{l}30 \\
16\end{array}$ \\
\hline 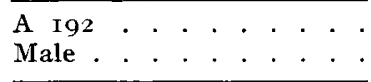 & $\begin{array}{l}6-9-76 \\
4-10-76\end{array}$ & $\begin{array}{l}\text { I0o } \\
\text { 100 }\end{array}$ & $\begin{array}{l}34 \\
\text { I I }\end{array}$ \\
\hline 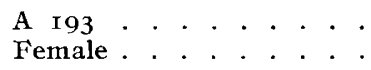 & $\begin{array}{l}6-9-76 \\
4-10-76\end{array}$ & $\begin{array}{l}\text { I0o } \\
\text { I00 }\end{array}$ & $\begin{array}{l}43 \\
22\end{array}$ \\
\hline
\end{tabular}

This spontaneous elimination of cells with chromosomal defects seems to affirm the doubts about the etiologic resp. pathogenetic role of autosomal breaks, because the possibility the breaks are caused for instance by an intervention in mitotic processes by virus particles in contaminated culture medium or by latent infections of the probands by IBR-IPV virus or others is not to be ruled out. 


\section{2. - Autosomal aneuploïdies}

In contrast to the tremendous role of numerous trisomies causing in human beings nea.rly ro typical malformation syndromes, and a high percentage of spontaneous abortions, in cattle this group is represented only by one singla trisomy, the trisomy $\mathbf{I} 8$.

The "trisomy 23 " found in several cases of nanism of calves in Rumania by Glunovschi et al. (I972) had not been established in other populations till now. Moreover the supernumerary autosom in those cases had not been identified by banding techniques.

\section{The " Lethal Brachygnathia Trisomy Syndrome" (LBTS) (Trisomy i 8 syndrome)}

and its cytogenetic background first had been published by HERzoG and HöHN in I968. Afterwards this syndrome combined with a trisomy of an autosome belonging to the group $\mathrm{C}$ had been established by MorI et al. (I969) in Japan, and, furthermore by DUNn et al. (I972) in U.S.A. In the meantime, we collected I 8 cases of LBTS in all breeds of our region, i. e. in

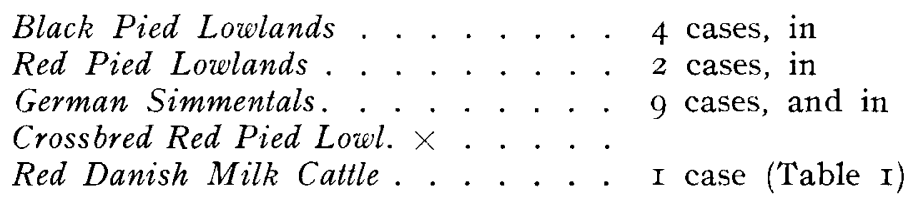

In present, we are not able to present a statistically proved assertion of the real frequencies of this syndrome, and the differences of frequencies between breeds, because in most cases the probands with the pathologic traits of LBTS are stillborn. Therefore, it is not possible to gain viable tissue cultures from them beyond the limit of 48 to 72 hours post mortem. Indeed, we get the impression, that this autosomal aneuploidy gained a broader distribution, preferably in the German Simmental, than primarily supposed.

In this connection, we are allowed to discuss the identification of those autosome of the C group involved in the trisomic process, and, which had been identified by the Standardization Conference of Reading 1976 to be the autosome No. I7. In regard to the statistical impossibility to separate the autosome No. I7 from No. I 8 by biometrical methods (arm length) it seems to be without any significance to destine the position of both autosomes in the karyogram more or less arbitrary (fig. 3). Therefore, we prefer to insist in the original designation of " trisomy I 8 " preliminary ascertained in our first publication of Ig68 (HERzoG and HöHN) before usage of banding techniques. 

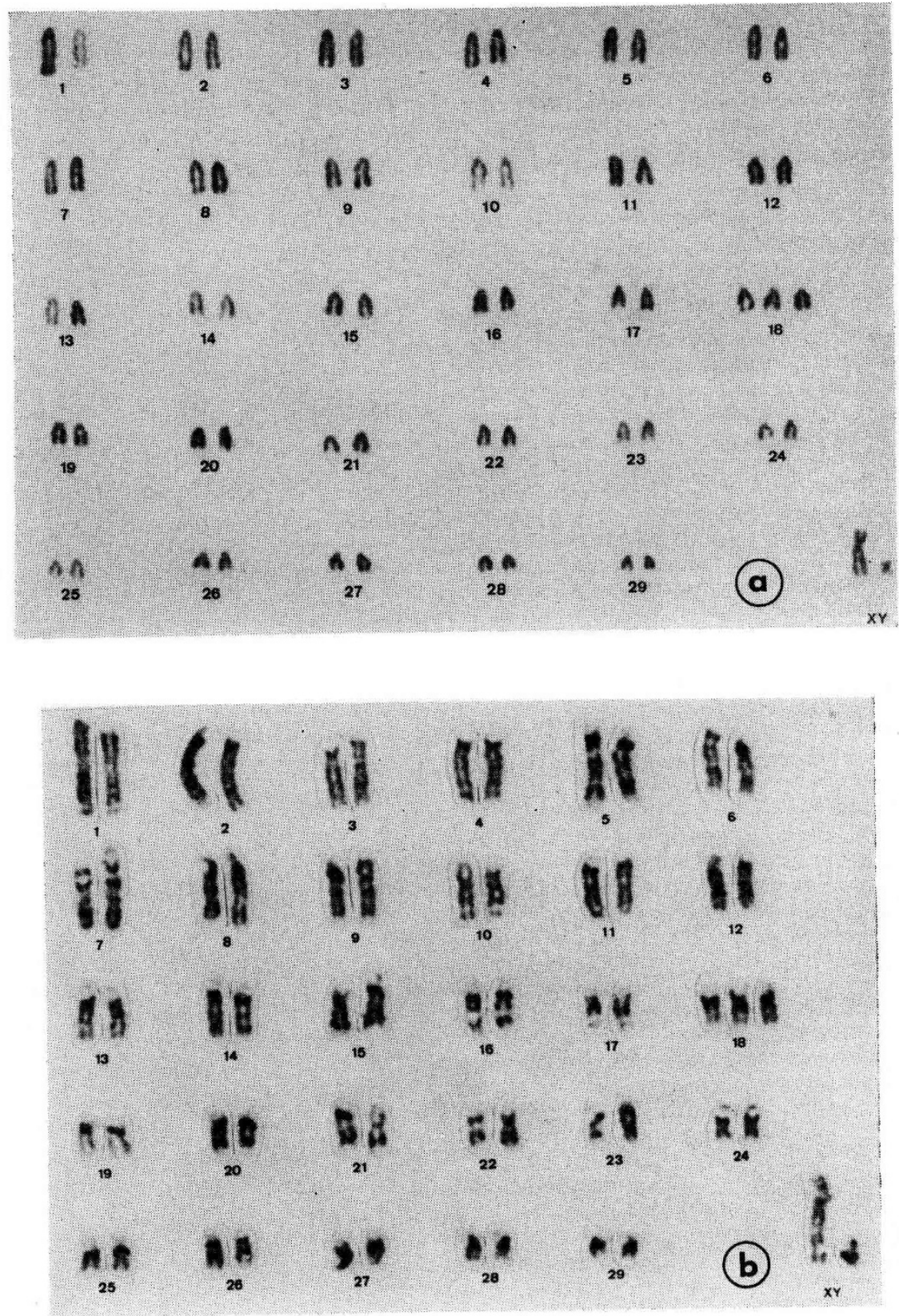

FIG. 3. - Identification of the trisomic autosom with autosom No. $18 \overline{8}$.

a) Empirical arrangement without banding (orcein painting).

b) Identification by means of $\mathrm{G}$ banding technique.

Identification de la trisomie autosomale $n^{0} \quad$ I8

a) Arrangement empirique sans marquage (coloration à l'orcéine).

b) Identification au moyen de la technique de marquage $\mathrm{G}$. 


\section{Pathology of the Lethal Brachygnathia Trisomy Syndrome}

The association of several different types of congenital malformations composing the LB'T syndrome had been analyzed by means of autopsies of the I 8 probands; the results are summarized in the following Table 7 :

\section{TABLE 7}

Phenotypical traits of the Lethal Brachygnathia Trisomy Syndrome $(\mathrm{N}=\mathrm{I} 8)$ Phénotype des animaux atteints de trisomie $18(\mathrm{~N}=\mathrm{I} 8)$

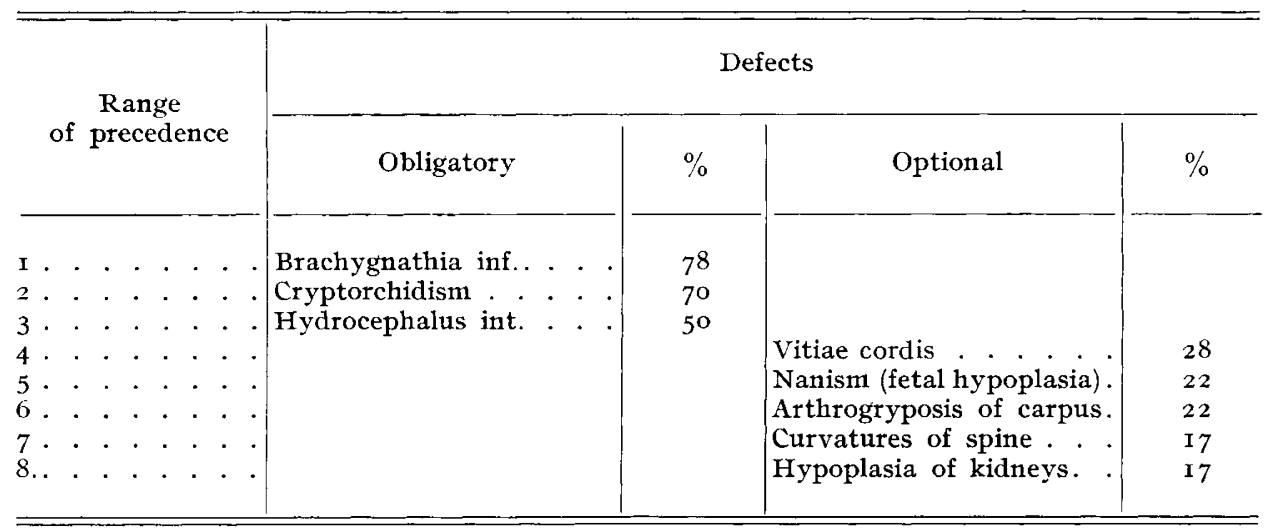

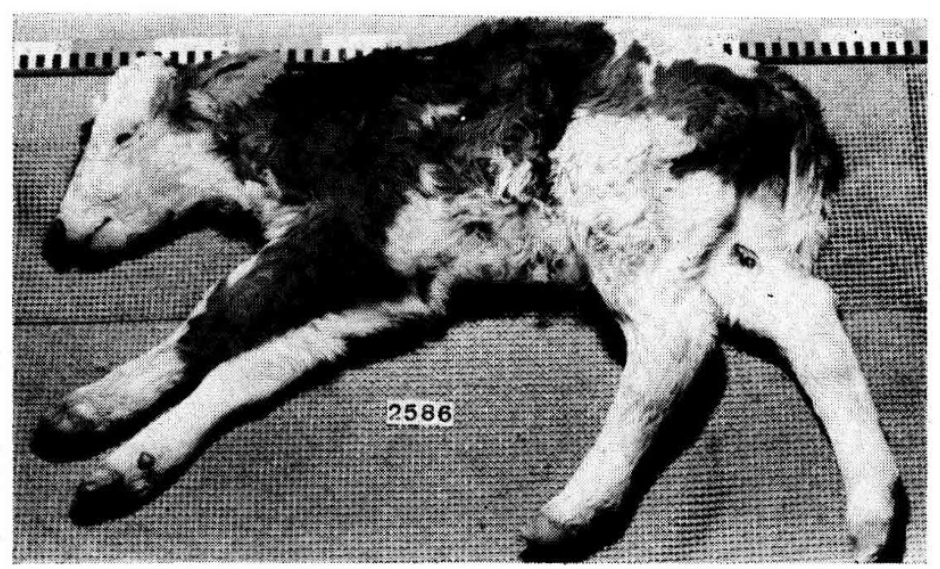

FIG. 4. - " Regular" phenotype of bovine LBT syndrome: Stillborn male calf with trisomy I8, brachygnathia inf., kyphoscoliosis, anomaly of gyration of cerebrum, hypoplasia of cerebellum, cryptorchidism and aplasia of scrotum. Normal birth weight (Red Pied Lowland, Reg. No. $2586 / 70)$.

Phénotype classique d'un veau atteint du syndrome LBT : Veau mâle mort-né avec la trisomie I8, brachygnathie inférieure, kyphoscoliose, anomalie des circonvolutions cérébrales, hypoplasie du cervelet, cryptorchidie et aplasie du scrotum. Poids à la naissance normal (Pie rouge des Plaines, cas $\left.n^{\circ} 2586 / 70\right)$. 
Other incidentally defects observed in LBTS probands are:

- Maxillo-facial dysplasia, mostly connected with

- Palatoschisis (cleft palate),

- Aplasia of cerebellum,

- Ascites and Hydrothorax,

all with a high variability of manifestation and combination of traits. Apparently the structure of this syndrome on no account is homogeneous: several probands with trisomy I8, partially with trisomy I 8 mosaics, deviate from the scheme presented in Table 7 . We like to quote as illustrations of those irregular types, the
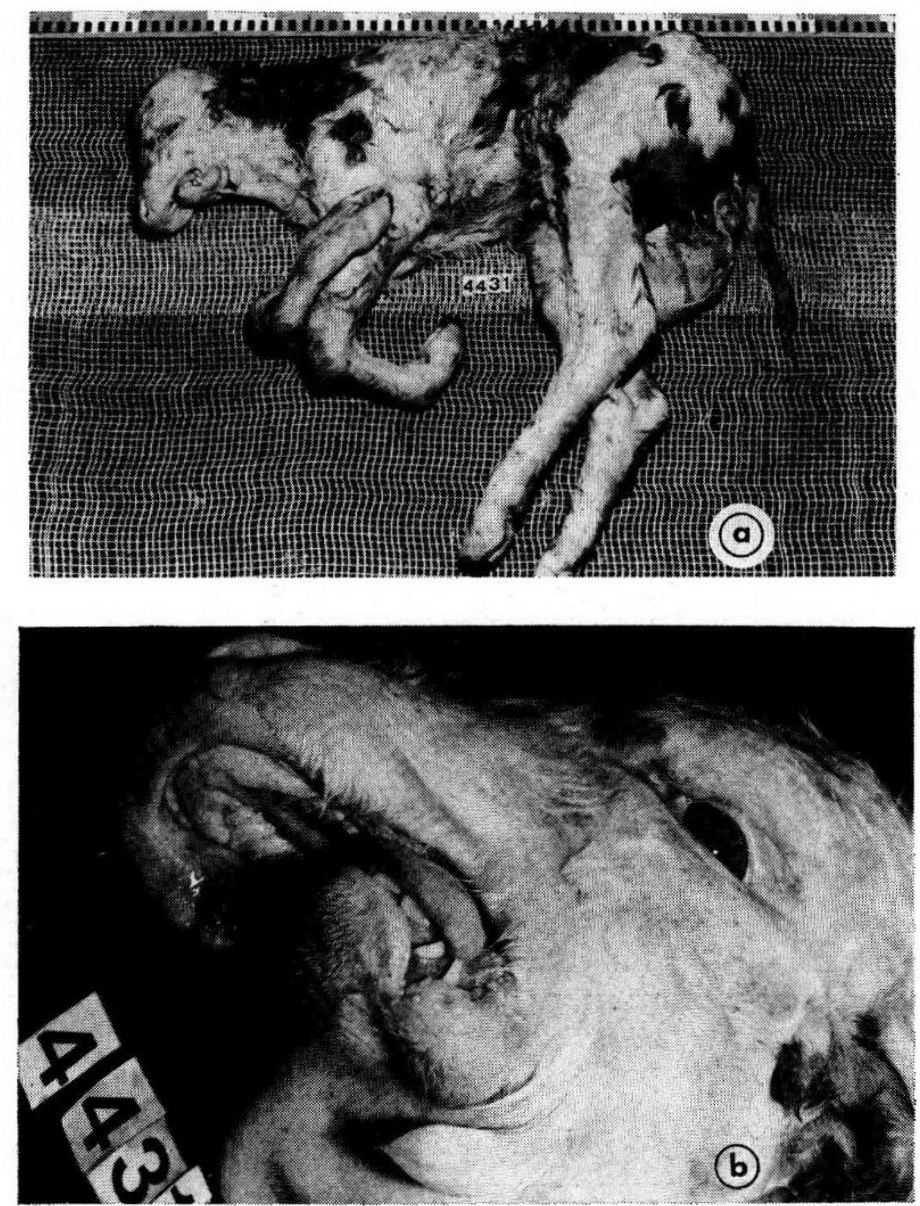

FIG. 5. - Exceptional phenotype of LBT syndrome: Stillborn male calf with trisomy I8, extreme dysplasia of mandible and cleft palate (b), hydrocephalus int., Cryptorchidism, extremely high birth weight $(43,6 \mathrm{~kg})$, carpal arthrogryposis (a) (German Simmental, Reg. No. 443I/76).

Phénotype inhabituel du syndrome LBT : Le veau mâle mort-né atteint de trisomie I8 présentait une dysplasie extrême de la mandibule avec une fissure palatine (b) une hydrocéphalie interne, une cryptorchidie, un poids à la naissance assez élevé $(43,6 \mathrm{~kg})$, une arthrogrypose du carpe (a) (Simmental allemand, cas $\left.n^{0} 443 I / 76\right)$. 
case with a trisomy mosaic $(60, \mathrm{XX} / 6 \mathrm{I}, \mathrm{XX}, \mathrm{I} 8+)$ exhibiting extremely severe dysplasias of the face, hydrocephalus, cleft palate, and multiple arthrogrypotic anomalies of all limbs, HERzOG and HöHN published in I974. During I976 a similar case with dysplasia of mandible, cleft palate, arthrogryposis of front limbs, and gigantic development had been registered (fig. 5). The karyotype of this stillborn calf (Reg. No. 443I/76) revealed roo p. cent of trisomy I 8 metaphase in cultured kidney cells.

\section{Etiology of LBT syndrome}

The empiric impression, the LB'T-syndrome being genetically influenced, is derived from several observations of its familiar incidence in the breed German Red Pied Lowlands as well as in German Simmentals. "Especially in the descent of two bulls belonging to the last mentioned breed used in A.I. we found three different types of meiotic disturbances, which are establishing the initial supposition of "an inherent genetical disposition to meiotic disturbances" in these families, we uttered in I970. In this paper we demonstrated the occurrance of one case of XXY-syndrome, and another with X-trisomy in one half sib group. 1975 and 1976 these observations had been supplemented by three cases of trisomy I 8 (fig. 6). Moreover, one of the involved bulls, the Divo I744 brought during the past Io years on the whole 7 descendents with the Lethal Brachygnathia Fetal Hypoplasia Syndrome (Table 8), all stillborn. Out of this reason we succeeded only in two cases (4I62 and 4348 ) in gaining viable tissue cultures post mortem, mostly from kidneys, and to demonstrate the trisomy $I 8$.

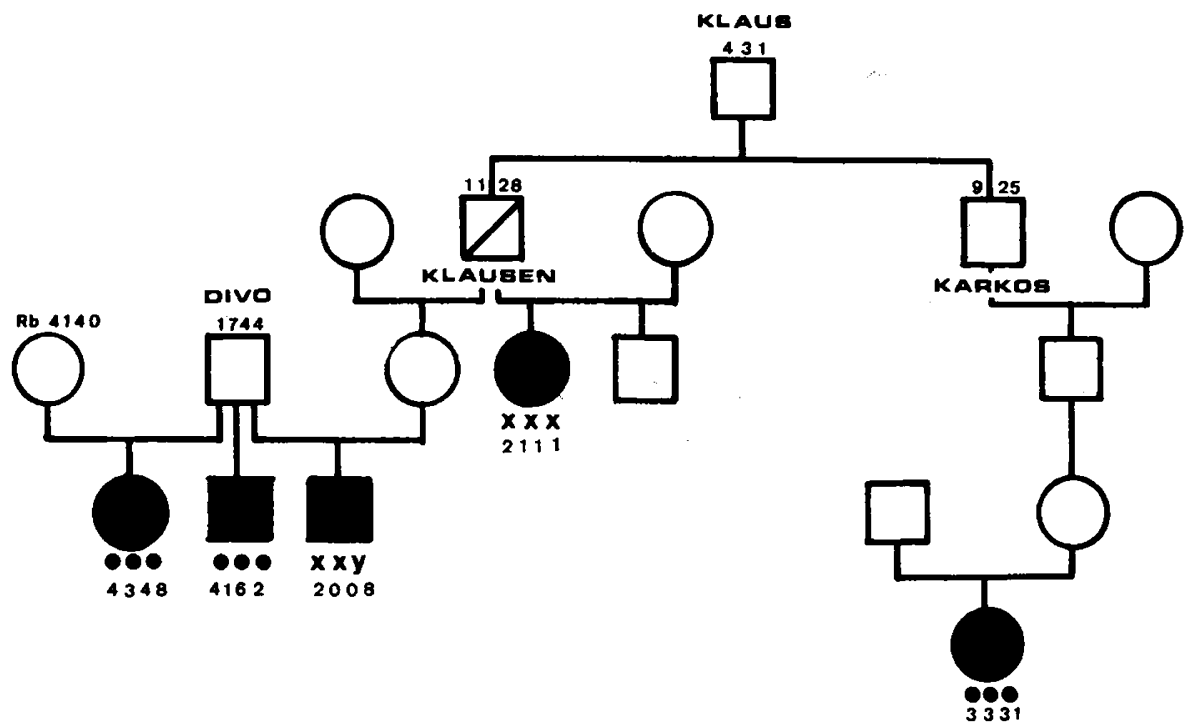

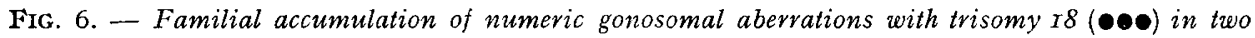
families of Simmental bulls. (Compare with RIECK et al., I970.)

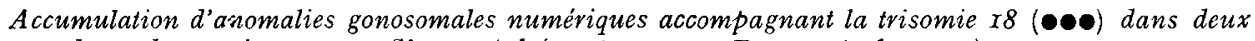
descendances de taureaux Simmental (comparer avec RIEck et al., I970). 
TABLE 8

Teratogram of the Simmental bull DIVO 1744

Used in A.I. from 8-9-I966 till presence

First inseminations: 17 ooo. Descendents: $\sim 12400$

Tératogramme du taureau Simmental DIVO I744 utilisé en I.A. depuis le 8-9-I966: I7 ooo pour inséminations premières, I2 ooo descendants

\begin{tabular}{|c|c|c|c|c|c|}
\hline * & $\mathrm{I}$ & I 3 I 8 & 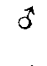 & $2-7-67$ & $\begin{array}{l}\text { Brachygnathia inf., Palatoschisis, Skoliose LWS, Zystennieren, } \\
\text { Kryptorchismus, allg. fetale Hypoplasie. }\end{array}$ \\
\hline$*$ & 2 & I 400 & $\widehat{\sigma}$ & $3 I-10-67$ & $\begin{array}{l}\text { Brachygnathia int., Hydrocephalus int., Kryptorchismus, Ku- } \\
\text { gelherz, allg. fetale Hypoplasie (Nanismus). }\end{array}$ \\
\hline & 3 & 2008 & 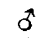 & $24-x 0-67$ & XXY-Syndrom: Kastratentyp, bilaterale Hodenhypoplasie. \\
\hline & 4 & $335^{\mathrm{I}}$ & q & $I-I-73$ & $\begin{array}{l}\text { Atresia ani, Rectovaginal-Fistel, Stenose der Urethra, Cor tri- } \\
\text { loculare biatrium. }\end{array}$ \\
\hline * & 5 & 3356 & 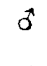 & $12-1-73$ & $\begin{array}{l}\text { Brachygnathia inf., Palatoschisis, Ascites congenita, Scrotuma- } \\
\text { plasie, Kryptorchismus, Ventrikelseptum-Defekt. }\end{array}$ \\
\hline & 6 & 3453 & $\sigma$ & $2-5-73$ & Anophtalmie-Anurie-Syndrom. \\
\hline$*$ & $\begin{array}{l}7 \\
8\end{array}$ & $\begin{array}{l}347^{8} \\
3783\end{array}$ & $\begin{aligned}+0^{*} \\
0\end{aligned}$ & $\begin{array}{l}25-4-73 \\
26-12-73\end{array}$ & $\begin{array}{l}\text { o: Aplasia bulbi sin., Ankyloblepharon. } \\
\text { Brachygnathia inf., allg. fetale Hypoplasie (Nanismus). }\end{array}$ \\
\hline & 9 & 3791 & $\sigma$ & $17-4-74$ & Palatoschisis, Karpalarthrogrypose bdsts. \\
\hline$\square$ & Io & 4162 & 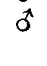 & $10-10-75$ & $\begin{array}{l}\text { Brachygnathie-Trisomie-Syndrom: Allg. fetale Hypoplasie, Hydro- } \\
\text { cephalus int., Cryptorchism. inguin. bilat. }\end{array}$ \\
\hline & II & $4 \mathrm{I} 85$ & 우 & $24-9-75$ & Brachyurie. \\
\hline$\square$ & 12 & $434^{8}$ & q & II- $5-76$ & $\begin{array}{l}\text { Brachygnathie-Trisomie-Syndrom: Allg. fetale Hypoplasie, Hydro- } \\
\text { cephalus int., Hydrothorax + Ascites congen. }\end{array}$ \\
\hline & I3 & 4390 & 0 & $10-7-76$ & Palatoschisis, Hydrothorax. \\
\hline * & $I_{4}$ & 4617 & 우 & $8-3-77$ & $\begin{array}{l}\text { Brachygnathia inf., allg. fetale Hypoplasie (Nanismus), Palatos- } \\
\text { chisis, Hydrocephalus int. }\end{array}$ \\
\hline
\end{tabular}

Frequency of malformations: $\mathbf{r}: 885$ (o.r I \%)

(*) Stillborn calves, karyotyping not possible.

$\square$ Stillborn calves, viable post mortem tissue cultures and successful karyotyping.

Those relative seldom observations, self-evident, are not suitable for calculating a mode of heredity involved with the manifestation of the LBT syndrome, because in both systems of heredity, in the monogenic and in the polygenic, it depends on the frequencies of the corresponding genes in the population, which are absolutely unknown. But, the unique accumulation of meiotic resp. mitotic disturbances in two families among some hundreds of unsuspicious sibships steadily controlled in the breeds of our region rules out an accidental coincidence of such rare events.

In human cytogenetics it have been reported about " familial chromosomal aberrations " (ZELLWEGER, I966) or about " recurrent aneuploidies" in certain families (IINUma et al., I973) relatively often during the last I7 years. Not only the appearance of different types of autosomal trisomies in consecutive pregnancies are kept in mind here, but those of autosomal together with gonosomal aneuploidies in various combinations in sibships and in consecutive generations of certain families. Such as trisomy E together with trisomy 2I, trisomy $2 \mathrm{I}$ with trisomy $\mathrm{X}$ (SINGER et al., I972), trisomy $2 \mathrm{I}$ and KLINEFELTER'S syndrome (IINUMA et al., I973). Concluding from those observations " the presence of a familial tendency to non disjunction cannot be disregarded "I InUma et al. stated I973. Considering the detection of a trisomy $I 8$ and a trisomy $2 \mathrm{I}$ in half-siblings, both from different fathers, DAvid and Jones conclude I975 that it may be possible that in some 
woman is a predisposition to nondisjunction. Their opinion, certain families apparently being " more prone to the occurrence of chromosomal aneuploidy", we estimate - together with all observations mentioned above- as confirmation of our hypothesis of a "familial disposition to meiotic disturbances " in cattle, we postulated in I970 (RIFCK et al.). Furthermore, we appreciate the appearance of two cases of LBTS (with proved trisomy I8), and several more cases of a from pathological point of view identical malformation syndrome (without evidence of a trisomy because the probands have been stillborn) in the half-siblings group of the bull Divo (Teratogram (Table 8) as a further proof for the same genetic background of the autosomal and gonosomal aneuploidies and their pathological effects.

\section{3. - Polyploïdies}

Polyploidies in general are incompatible with vitality of mammals. Nevertheless, some cases in human infants with triploidies (69, XXX) have been published in the past five years. Some of them survived to birth, others even nine days post partum (DE GROUCHY et al., I974). In cattle, too, tetra- to dekaploidies have been found in individuals of Charolais cattle with double muscled condition (culard) in percentages from I7 to $24 \mathrm{p}$. cent of examined cells (POPESCU, I968).

One of us (RIECK) demonstrated I973 a case of diploidy/triploidy mosaicism in a German Simmental individual, quite a similar case DunN et al. published in r970. The XXY gonosomal complement of this mosaic obviously was the cause of masculinization of the gonads, and of disturbances of differentiation of the sinus urogenitalis. This type of polyploidy seems to remain a unique case.

Some doubts about the etiological role, resp. pathogenetic significance of certain chromosome anomalies have been mentioned above. Apparently this turns out to be true in a high degree concerning the polyploidies observed in white blood cell cultures.

This problem grew acute in human genetics considering the observations, that up to Ioo p. cent polyploidy has been found in cultures of amnioticfluid cells gained by amniocentesis from pregnant women with normal diploid embryos. It has been suggested that prolonged cultivation of cells increases the frequencies of polyploid cells. This tendency to disturbances of mitosis in cells in culture could be avoided by introduction of a special technique (NAKAKOME et al., I972).

In regard to our experience with a " control group " of nearly one thousand routine charges of tissue cultures we believe to possess sufficient estimations of frequencies of polyploid cells cultured from normal animals. The observations on chorionic cells of human beings, therefore, may not be verified in bovine cells of streaming blood, and of other organs. In comparison with our results obtained in the " control group" the significance of polyploidy findings statistically may be proved, self-evident on the assumption of constant conditions of culture techniques. Out of this reason we are convinced the polyploidies not to be artificial products of culture techniques, but representing a symptom of lability of cells in performing the mitotic processes in culture. This seem to be the case especially in endomitotic polyploidies, in most cases tetraploidies, observed in nearly 25 probands with congenital defects of central nervous system and eyes of newborn calves (HERZOG and HöHN, I97I). Those findings recently have been confirmed by further observations in the same category of defects by STIx (I978). The 
same functional lability of mitosis in culture WEINHOLD demonstrated conclusively I970 in aneuploid and polyploid white blood cells and tumor cells of cows with lymphatic leukaemia, estimating this phenomenon to be a fundamental charac teristic of mitotic disturbances of tumor cells.

Cells which reveal the tendency to polyploidization in culture are estimated in human oncology to be a " characteristic feature of malignant change " of a blastoma (KNOERR-GäRTNER, H. and M., I977).

This interesting phenomenon of abnormal cellular functional behaviour in realization of mitosis in culture is till now very poorly understood. It requires further investigation, because its explanation with disturbing influences by culture medium, mentioned above, apparently not at all is its only cause. In teratological aspects it is to evaluate whether cell types exhibiting polyploidization in culture may have similar or homologous effects on developmental processes of certain blastema (neuroblastema f. i.) in embryos as in malignant blastomas.

Hence, we may infer, that the problem of polyploidy in mammals include two items:

(I) Polyploid cells in culture are they a symptom of cellular functional lability, resp. insufficiency, to realize mitotic processes in artificial medium, or,

(z) are they originally present in blood cells or cells of other organs, and, assertive, how many percent of polyploid cells in mosaics are sufficient to disturb the embryological development or to individual mortality?

\section{4. - Gonosomal numeric anomalies including gonosomal chimaeras}

The most comprehensive contingent of chromosomal aberrations presented in Table I is represented by the gonosomal numeric anomalies, first of all the $\mathrm{XX} / \mathrm{XY}$ chimerism of freemartins, and other gonosomal mosaics. Notwithstanding the high share of this type of blood chimerism, the XX/XY chimerism possess little significance in connection with the present discussion, because the frequency of freemartins only depends from the frequencies of dizygotic twins in the different breeds. High interest, indeed, is to be claimed to the problem of the $\mathrm{XX} / \mathrm{XY}$ mosaicism in singleborn animals and in isosexual twins. Although the reports on this extraordinary type of gonosomal mosaicisms seem to increase recently, the frequency of the so called "Autonomous $\mathrm{XX} / \mathrm{XY}$ syndrome" in the breeds of Germany is very low. The last case we observed in Black Pied Lowlands in r 974 in the environment of Hanover (RIECK, I975). The pathogenic activity of those second $\mathrm{X}$-chromosome in genetic male individuals, obviously originating from a "whole body mosaicism" (BENIRSCHKE, I970) seem to be rather obscure in the present. Partially those $\mathrm{XX} / \mathrm{XY}$ individuals are absolutely normal, another part of them exhibit more or less severe disturbances of differentiation of sexual organs within wide limits of variation.

Likewise very low population frequencies in German breeds exhibit the gonosomal trisomies, $\mathrm{i}$. e. the bovine XXY syndrome, a homologue to the human KLINEFELTER's syndrome, and the trisomy $X$. Since I967 (RIECK, I970), and I 970 no further gonosomal trisomy had been observed. A symptom of their scarcity in other European cattle breeds, too, is the finding of only one more case of 
an X trisomy in a heifer of the Norwegian Red cattle in 1976 (NORBERG et al., I976), not at all in all other breeds in the world.

Most of the cases of intersexuality or of malformations of sexual organs without intersexuality in cattle are not combined with (or caused by (?)) gonosomal aberrations.

\section{Conclusions}

In spite of a large amount of karyograms which had been collected in the course of etiological research of developmental disturbances in cattle during the last ten years it is impossible in the present moment to gain an impression of true frequencies of chromosomal anomalies, considering the lack of comprehensive investigations of whole of the population. Moreover, the fact, relatively seldom to obtain surviving cells from stillborn calves being fit to divide in tissue culture make it impossible to get real figures of frequencies of chromosomal defects. Nevertheless the findings of chromosomal anomalies associated with congenital malformations in newborn calves, or with clinical symptoms in adolescent animals allow some rough estimations of their frequencies and their economic importance. So, it is evident that the incidence of trisomy 18 in all breeds just follow that of I $/ 29$ translocation; the frequencies of all other chromosome aberrations are ranging widely below those just mentioned.

Considering the chromosome aberrations specialized in groups of anomaly types it had been found within the group of structural autosomal defects cases of hereditary nanism combined with breakages in the sibship of a bull of German Simmental breed; breakages and reunion figures in calves suffering from Hereditary parakeratosis ("Zinc deficiency syndrome ") in Black Pied Lowlands, furthermore breakages too in a solitary case of hydrocephalus, rachimyeloschisis etc. The group of numerical autosomal aberrations (aneuploidy) is represented by the trisomy I 8 alone, causing the "Lethal Brachygnathia Trisomy Syndrome "; whereas the group of polyploidies mainly consisted in tetraploidies observed in primary cultures of blood cells originating from several cases of different defects of the central nervous system.

The etiological role of structural anomalies of autosomes in disturbances of embryological development is not quite clear yet. It is not known whether the chromosome defect is merely a symptom in the range of others within a syndrome, or, whether it reveals pathological effects autonomously in sense of an effective etiological factor. But, there is strong evidence autosomal breaks being markers for heterozygosity of healthy parents of calves with Hereditary parakeratosis.

The group of gonosomal numerical anomalies is represented particularly by the XXY syndrome, the " Bovine hypogonadism ", and the X trisomy, both being very seldom in the observed populations. The different mosaicisms, i. e. the diploidy/triploidy mosaic, include of course a multiplication of gonosomes in triploid cells resulting in disturbances of genital development such as the different types of intersexuality. This group comprises also the "Autonomous XX/XY syndrome " in singletons and isosexual twins.

Certain observations exhibit a hereditary disposition of families to disturbances of meiotic and/or mitotic processes, based on the presence of autosomal together with gonosomal aneuploidies in two families of the German Simmental breed. 


\section{Résumé}

\section{Situation actuelle de la pathologie chromosomique dans différentes races bovines allemandes}

I. J)ans le but de préciser le rôle étiologique des anomalies chromosomiques en pathologie des animaux domestiques, des analyses caryotypiques ont été entreprises chez 847 veaux nouveaunés présentant des malformations congénitales, chez des bovins adultes atteints de maladies héréditaires et chez les individus ayant des malformations des organes génitaux. Ces travaux ont été réalisés parmi trois grandes races d'une population de Hesse pendant ces dix dernières années. On a trouvé $14 \mathrm{I}$ individus porteurs de diverses anomalies.

2. On n'a pu fournir qu'une estimation grossière des fréquences des anomalies chromosomiques dans la population observée en raison de l'impossibilité, d'une part de faire le caryotype de tous les veaux atteints d'anomalies congénitales (la plupart d'entre eux étant morts-nés) et d'autre part, d'étudier toute la population.

3. Les types d'anomalies chromosomiques les plus fréquemment rencontrés sont la translocation $\mathrm{I} / 29$ tout d'abord, suivie de la trisomie $\mathrm{r} 8$. Le chimérisme $\mathrm{XX} / \mathrm{XY}$ chez les freemartins n'a pas été considéré parce que sa fréquence ne dépend que de celle des faux jumeaux dans les différentes races. A l'heure actuelle, les fréquences réelles de ces deux types d'anomalies chromosomiques n'ont pas une importance économique digne d'attention dans la population observée. Toutes les autres anomalies, surtout les remaniements structuraux autosomaux existent seulement de façon sporadique, sauf accumulations chez certaines familles. C'est le cas pour la parakératose héréditaire bovine et pour le nanisme héréditaire.

4. L'existence de plusieurs animaux porteurs à la fois de la trisomie $\mathbf{r} 8$ et d'anomalie numérique des gonosomes, s'explique par une prédisposition familiale aux erreurs méiotiques.

5. Les syndromes ont été déterminés à partir des résultats d'autopsie des 18 cas de trisomie 18 et de ceux des 9 cas de parakératose héréditaire. Chez les parents des veaux atteints de parakératose on a mis en évidence une augmentation du nombre de cassures autosomales. Ceci pourrait servir de marqueur pour identifier les hétérozygotes dans les familles suspectées d'être vectrices de cette maladie.

\section{Zusammenfassung}

\section{Ubersicht ïber die neueste Situation der Chromosomen pathologie in verschiedenen deutschen Rinderrassen}

I. Mit dem Ziel der Aufklärung der ätiologischen Rolle von Chromosomenanomalien wurden bei den drei grossen Rassen der hessischen Rinderpopulation in den letzten ro Jahren bei 847 Tieren Karyotypbestimmungen durchgeführt. Es handelt sich dabei um Neugeborene mit kongenitalen Anomalien, um erwachsene Probanden mit genetisch beeinflussten Erkrankungen und um Individuen mit Missbildungen der Geschlechtsorgane. Bei I4I Probanden wurden Chromosomenaberrationen verschiedener Typen gefunden.

2. Da weitaus die meisten der mit morphologischen Anomalien behafteten Kälber tot geboren werden, eine Karyotypanalyse bei diesen daher nicht möglich und eine systematische cytogenetische Exploration der Gesamtpopulation technisch nicht durchführbar ist, können aus diesen Ergebnissen nur rohe Anhaltspunkte für die realen Frequenzen von Chromosomenanomalien in der untersuchten Population gewonnen werden.

3. In der Häufigkeit der einzelnen chromosomalen Anomalie-Typen steht - vom $\mathrm{XX} / \mathrm{XX}$ Chimärismus der Freemartins abgesehen — die x/29-Translokation an erster Stelle, gefolgt von der Trisomie I 8 . Beide besitzen wegen ihrer geringen tatsächlichen Frequenz in der beobachteten Population in der gegenwärtigen Situation nur eine geringe züchterische und ökonomische Bedeutung. Auch alle anderen morphologischen autosomalen Anomalien, vorwiegend in Gestalt von Brüchen, finden sich nur vereinzelt, jedoch familiär gehäuft bei der Bovinen Hereditären Parakeratose und beim erblichen Zwergwuchs. Die gonosomalen numerischen Anomalien werden ebenfalls selten angetroffen.

4. Das Auftreten mehrerer Probanden mit dem Trisomie r8-Syndrom (letales BrachygnathieTrisomie-Syndrom) gemeinsam in einer Familie, in der früher bereits Fälle von gonosomalen numerischen Anomalien festgestellt wurden, lässt auf eine familiäre Disposition für Mitosebzw. Meiosestörungen schliessen. 
5. An Hand der Autopsiebefunde von i 8 Fällen des Trisomie I8-Syndroms und der von 9 Fällen von Boviner Hereditärer Parakeratose wird die Symptomatik dieser von Chromosomenanomalien erzeugten, bzw. mit ihnen verbundenen Syndrome festgelegt. Dabei werden bei den Elterntieren von Parakeratose-Kälbern erhöhte Frequenzen von autosomalen Brüchen nachgewiesen. Diese können daher als Marker zur Erkennung von Heterozygoten in parakeratoseverdächtigen Familien herangezogen werden.

\section{Références}

Andresen E., Flagstad T., Basse A., Brummerstedt E., r97o. Evidence of a lethal trait, A 46 , in Black Pied Danish cattle of Friesian descent. Nord. Vet.-Med., 22, 473-485.

BENIRSCHKE K., I970. Spontaneous chimerism in mammals. A critical review. In: Current Topics in Pathology, ed. by H.-W. Altmann, K. Benirschke et al. Berlin. Heidelberg. New York : Springer, Ergebnisse der Pathologie, vol. 5I, I-6r.

David T. J., Jones A. J., I975. Trisomy $2 \mathrm{I}$ and trisomy $\mathrm{I} 8$ in half-siblings. Humangenetik, 27, $35 \mathrm{I}-35^{2}$.

DUNN H. O., MCENTEE K., HANSEL, W., 1970. Diploid-triploid chimerism in a bovine true hermaphrodite. Cytogenetics, 9, 245-259.

Dunn H. O., Johnson R. H. jr, I972. A 6I, XY cell line in a calf with extreme brachygnathia. J. Dairy Sci, 55, 524-526.

El-Nahass E., Michelmann H. W., Paufler S., 1976. Chromosomale Untersuchungen von Zucht- und Schlachtrindern. Zûchtungskunde, 48, 264-277.

ForD C. E., Evans E. P., I977. Cytogenetic observations on $\mathrm{XX} / \mathrm{XY}$ chimaeras and a reassessment of the evidence for germ cell chimaerism in heterosexual twin cattle and marmosets. J. Reprod. Fertil., 49, 25-33.

Gluhovschi N., BistriceanU M., I972. Cercetàri clinice si citogenetice in unele cazuri cu nanism la taurine. Lucràri Stiintifice, Sevia Med. Vet., 13, 429-433.

Grouchy J. DE, RoubIN M., RISSE J. C., ŞARruT S., I974. Enfant triploide (69, XXX) ayant vécu neuf jours. Ann. Génét., 17, 283-286.

HARVey M. J. A., Logue D. N., I975. Studies on the $13 / 21$ Robertsonian translocation in Swiss Simmental catle. 2. Europäisches Kolloquium über Zytogenetik (Chromosomenpathologie) in Veterinärmedizin, Tierzucht und Säugetierkunde, Giessen 1975, I 55-16r .

Herzog A., HöHN H., I968. Autosomale Trisomie bei einem Kalb mit Brachygnathia inferior und Ascites congenitus. Dtsch. tievärztl. Wschr., 75, 604-606.

HeRzoG A., HöHN H., I97I. Zytogenetische Befunde bei angeborenen Anomalien des Zentralnervensystems des Rindes. Ann. Génét. Sél. anim., 3, 225-234.

HeRzog A., Höhn H., I97I. Chromosomendefekte bei der erblichen Parakeratose des schwarzbunten Kalbes. Giessener Beitr. Erbpath. Zuchthyg., 3, I-6.

Herzog A., I974. Autosomale Trisomie bei der letalen Brachygnathie des Rindes (bovines Trisomie-Brachygnathie-Syndrom). Dtsch. tievarztl. Wschr., 81, 78-80.

IINUMA K., NAKagome Y., Matsur I., 1973. $2 \mathrm{r}$ trisomy and prenatally diagnosed XXY in two consecutive pregnancies. Hum. Hered., 23, 467-469.

KNOERR-GaERTNER H., SchuhManN R., KRAUS H., UEBELE-Kallhard'T B., I977. Comparative cytogenetic and histologic studies on early malignant transformation in mesothelial tumors of the ovary. Hum. Genet., 35, $28 \mathrm{I}-297$.

LEGG S. P., SEARS L., I960. Zinc sulphate treatment of parakeratosis in cattle. Nature, 186, I06r.

Miller J. K., Miller W. J., I960. Development of zinc deficiency in Holstein caives fed a purified diet. J. Dairy Sci., 43, I854.

MORI M., SaSaki M., Makino S., Ishikawa T., Kawata K., I969. Autosomal trisomy in a malformed newborn calf. Proc. Japan Acad., 45, 955-959.

NaKagome Y., InNuma K., Matsunaga E., 1972. Polyploidy in cultured amniotic-fluid cells. Lancet, 11, 387 .

Norberg H. S., Refsdal A. O., Garm O. N., Nes N., r976. A case report on X-trisomy in cattle. Hereditas, 82, 69-72.

PoPESCU C. P., I968. Observations cytogénétiques chez les bovins Charolais normaux et culards. Ann. Génét., 11, 262-264.

REFSDAI, A. O., I976. Low fertility in daughters of bulls with $1 / 29$ translocation. Acta vet. scand., 17, I90-I95.

Rieck G. W., Höhn H., Herzog A., I970. X-Trisomie beim Rind mit Anzeichen familiârer Disposition für Meiosestörungen. Cytogenetics, 9, 40I-409. 
RIECk G. W., I970. Das XXY-Syndrom beim Rind (Boviner Hypogonadismus). I. Europäisches Kolloquium über Zytogenetik (Chromosomenpathologie) in Veterinärmedizin und Säugetierkunde, Giessen 1970. Sonderheft I der Giessener Beiträge zur Erbpathologie und Zuchthygiene, I38-I 45 .

RIECK G. W., I973. Numerical aberrations of gonosomes and reproductive failure in cattle. Symposium on Chromosomal Errors in Relation to Reproductive Failure, Paris I973, I65-187.

RIECK G. W., I975. Zur Problematik des autonomen $X X / X Y$-Syndroms beim Rind. 2. Europäisches Kolloquium ûber Zytogenetik (Chromosomenpathologie) in Veterinärmedizin, Tierzucht und Säugetierkunde, Giessen 1975, 2 12-235.

Singer J., Sachdeva S., Smith G. F., KSIA D. Y. Y., I972. Triple X female and a Down's syndrome offspring. J. med. Genet., 9, 238-239.

Srrx K. A., Chromosomenanomalien bei angeborenen Missbildungen des Zentralnervensystems des Rindes (Vet. med. Diss, Giessen (in preparation).

STÖBER M., I97I. Parakeratose beim schwarzbunten Niederungskalb. I. Klinisches Bild und Ätiologie. Dtsch. tierärztl. Wschr., 78, 257-265.

Stöber M., PitTermann D., KLug E., I974. Beitrag zur erblich bedingten Parakevatose des schwarzbunten Niederungskalbes. Io. Kongress der Deutschen Veterinärmedizinischen Gesellschaft, Bad Nauheim I973, Paul Parey, Berlin, Hamburg, Fortschritte der Veterinärmedizin, Heft 20, I65-I7I.

STrANZinger G. F., Förster M., I976. Autosomale Chromosomentranslokationen beim Fleckund Braunvieh. Experientia, 32, 24-27.

Trautwein G., I97I. Parakeratose beim schwarzbunten Niederungskalb. 2. Pathologischanatomische Befunde. Dtsch. tierärztl. Wschr., 78, 265-270.

WEINHOLD E., I970. Chromosomenuntersuchungen bei der Rinderleukose. I. Europäisches Kolloquium über Zytogenetik (Chromosomenpathologie) in Veterinärmedizin und Säugetierkunde, Giessen I970, Sonderheft I der Giessener Beiträge zur Eirbpathologie und Zuchthygiene, I I9-I 26.

WeismanN K., Flagstad T., I976. Hereditary zinc deficiency (Adema disease) in cattle, an animal parallel to acrodermatitis enteropathica. Acta Dermat. Venereol., Stockholm, 56, r 5 I-r 54 .

ZELLWEGER H., I966. Familial chromosomal aberrations. Ann. paediat., Basel, 206,38 r-395. 